\title{
A previously unrecognized radiation of ranid frogs in Southern Africa revealed by nuclear and mitochondrial DNA sequences
}

\author{
Arie van der Meijden ${ }^{a}$, Miguel Vences ${ }^{b}$, Simone Hoegg ${ }^{a}$, Axel Meyer ${ }^{\mathrm{a}, *}$ \\ ${ }^{a}$ Lehrstuhl für Zoologie und Evolutionsbiologie, Department of Biology, University of Konstanz, 78457 Konstanz, Germany \\ ${ }^{\mathrm{b}}$ Institute for Biodiversity and Ecosystem Dynamics, Zoological Museum, University of Amsterdam, Mauritskade 61, \\ 1092 AD Amsterdam, The Netherlands
}

Received 17 January 2005; revised 1 May 2005

Available online 21 June 2005

\begin{abstract}
In sub-Saharan Africa, amphibians are represented by a large number of endemic frog genera and species of incompletely clarified phylogenetic relationships. This applies especially to African frogs of the family Ranidae. We provide a molecular phylogenetic hypothesis for ranids, including 11 of the 12 African endemic genera. Analysis of nuclear (rag-1, rag-2, and rhodopsin genes) and mitochondrial markers (12S and $16 \mathrm{~S}$ ribosomal RNA genes) provide evidence for an endemic clade of African genera of high morphological and ecological diversity thus far assigned to up to five different subfamilies: Afrana, Cacosternum, Natalobatrachus, Pyxicephalus, Strongylopus, and Tomopterna. This clade has its highest species diversity in southern Africa, suggesting a possible biogeographic connection with the Cape Floral Region. Bayesian estimates of divergence times place the initial diversification of the southern African ranid clade at $\sim 62-85$ million years ago, concurrent with the onset of the radiation of Afrotherian mammals. These and other African ranids (Conraua, Petropedetes, Phrynobatrachus, and Ptychadena) are placed basally within the Ranoidae with respect to the Eurasian groups, which suggests an African origin for this whole epifamily.
\end{abstract}

Keywords: Amphibia; Ranidae; Cacosterninae; Petropedetinae; Pyxicephalinae; Raninae; Tomopterninae; Molecular phylogeny; Conservation priorities; Biodiversity hotspot; Africa

\section{Introduction}

The recent report of the Global Amphibian Assessment project (Stuart et al., 2004) shows that at least a disturbing $42 \%$ of amphibian species are experiencing declines, in large part due to still unknown processes. In some cases entire diverse clades of frogs are heavily declining (Lötters et al., 2004). Such non-random extinctions can lead to a severe loss of evolutionary history (Purvis et al., 2000) and a reliable phylogeny of all amphibians is needed to identify them. In several very species-rich cosmopolitan groups of frogs the phyloge-

\footnotetext{
* Corresponding author. Fax: +49 7531883018.

E-mail address: axel.meyer@uni-konstanz.de (A. Meyer).
}

netic relationships are still insufficiently known. This lack of a robust phylogenetic hypothesis is especially true for the family Ranidae or True Frogs that contains over 700 species, which are distributed throughout the world. A single genus (Rana) is thought to occur on all continents except Antarctica. Yet the phylogenetic relationships among Rana, and ranids in general, are largely uncharted (Emerson et al., 2000b). Recent molecular studies have provided important progress in the understanding of ranids and their related groups (Bossuyt and Milinkovitch, 2000; Hoegg et al., 2004; Van der Meijden et al., 2004; Vences et al., 2003b). Some studies have identified India as a reservoir of ancient ranid lineages, and proposed these animals as a model for "Out of India" dispersal of vertebrates (Bossuyt and Milinkovitch, 2001; Roelants et al., 2004). These works demonstrated 
the potential of ranids to decipher general patterns of biogeography and diversification although only a part of the currently recognized ranid diversity has been studied so far. Because most of the endemic African ranid genera are still unstudied from a molecular perspective the biogeographical insights remain incomplete.

Despite recent compelling evidence for the ability for transoceanic dispersal in amphibians (Hedges et al., 1992; Vences et al., 2003b, 2004), there is little doubt that continental drift has had a major influence in shaping their current distribution and phylogeny. The close relationships of the recently discovered Nasikabatrachus from India with Nesomantis from the Seychelles strikingly demonstrated the importance of the Gondwanan breakup for the vicariance biogeography and hence phylogeny of these basal Neobatrachian frogs (Ranoidei sensu Sokol, 1977). Africa is generally seen as the place of origin for the current distribution of frogs in the superfamily Ranoidea (Biju and Bossuyt, 2003; Feller and Hedges, 1998; Savage, 1973), and one of its subclades, the Arthroleptoidae (Fig. 1), is endemic to this continent (with a few species in Madagascar and on the Seychelles).

Africa is renowned for several endemic radiations such as the Afrotherian mammals (Springer et al., 1997) and the haplochromine cichlid fishes (Verheyen et al., 2003). Africa was united with South America, Australia, Antarctica, India, and Madagascar in the supercontinent Gondwanaland until the end of the late Jurassic. After the breakup of Gondwanaland, Africa remained isolated until it connected with Eurasia. The India-Seychelles-Madagascar plate broke off from Africa 158 to 160 million years ago ${ }^{1}$ (mya), and Greater India started to drift northwards across the Indian Ocean about 96-84 mya (Briggs, 2003). The India-Madagascar plate has been suggested as possible biogeographic origin of Asian ranoid subclades (Duellman and Trueb, 1986; Bossuyt and Milinkovitch, 2001), i.e., the Rhacophoridae and at least part of the Ranidae.

Land bridges that connected Africa with Eurasia after its long isolation from other continents allowed Eurasian faunal elements to disperse into Africa, including several ranoid representatives. Species (1) of the dicroglossine genus Hoplobatrachus, (2) of the ranine lineage containing the genera/ subgenera Rana and Amnirana, and (3) the rhacophorid genus Chiromantis have dispersed into Africa from Eurasia (Kosuch et al., 2001; Vences et al., 2003b). Currently, 21 ranid genera are restricted in their distribution to Africa, most of which are limited to sub-Saharan Africa.

By analyzing nuclear and mitochondrial DNA sequences of representatives of all but one subfamily of ranids we here provide the first inclusive molecular phy-

\footnotetext{
${ }^{1}$ Abbreviations used: mya, million years ago; MP, maximum parsimony; ML, maximum likelihood; BI, Bayesian Inference; NJ, neighbour joining.
}

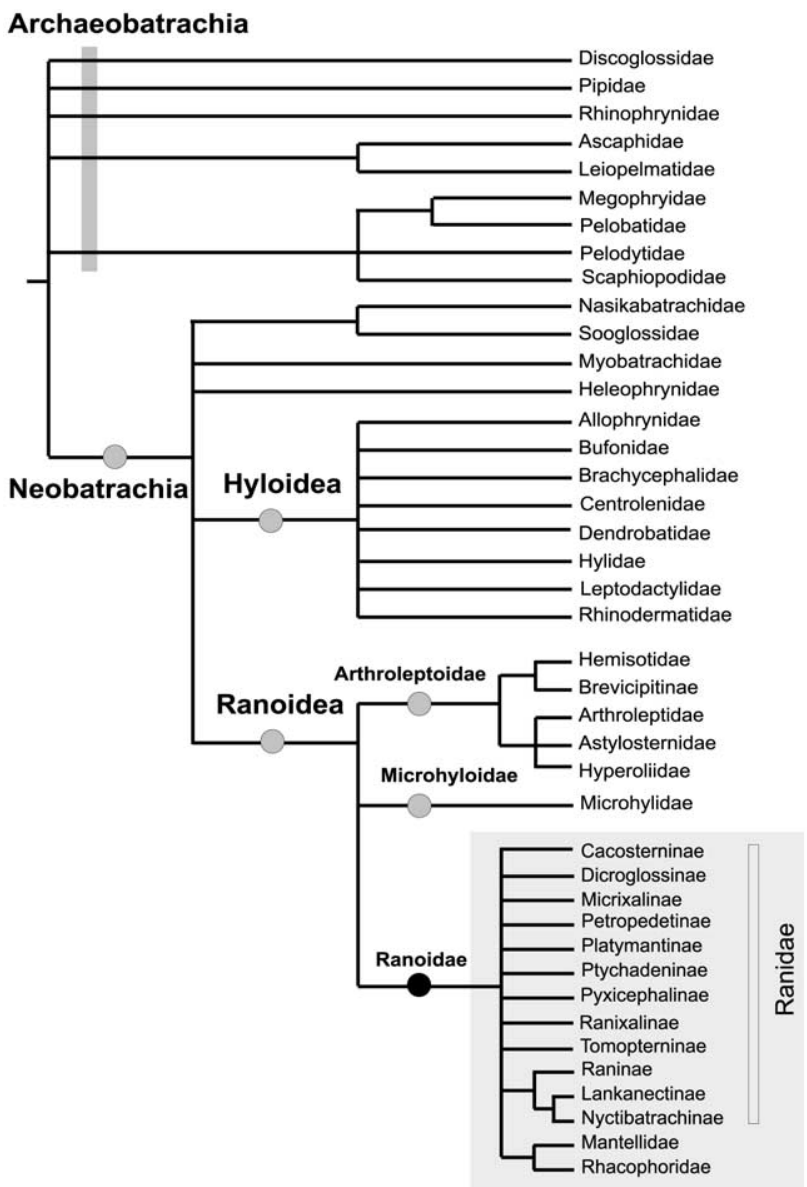

Fig. 1. Schematic representation of the classification of ranids and their phylogenetic position among frogs following Vences and Glaw (2001), with some additions from Dubois (1992) and BlommersSchlösser (1993), and with modifications from the trees of Biju and Bossuyt (2003), Dubois (2003), Hoegg et al. (2004), Roelants et al. (2004), Van der Meijden et al. (2004), and own unpublished data: the family Ranidae is a paraphyletic assemblage that together with the Mantellidae and Rhacophoridae forms the epifamily Ranoidae. Together with two other epifamilies (the Arthroleptoidae and Microhyloidae) they form the superfamily Ranoidea in the Neobatrachia. The familial scheme used here includes Bombinatoridae in Discoglossidae, and Limnonastidae and Rheobatrachidae in Myobatrachidae.

logeny of ranid relationships. Our data provide compelling evidence for a deep evolutionary history of many African endemic ranid groups and, unexpectedly, uncover an endemic radiation that includes taxa that had so far been classified into up to five different subfamilies.

\section{Materials and methods}

\subsection{Taxonomy and selection of taxa}

Duellman and Trueb's (1986) characterization of ranid systematics being 'in a state of chaos' has been heavily quoted but the situation has not much improved 
since. As a convention we here follow the taxonomic scheme of Vences and Glaw (2001), with some modifications from more recent research as outlined in Fig. 1. At present, accepting the proposals of subfamilial arrangement by Dubois and Ohler (2001) and Roelants et al. (2004) to the classifications of Dubois (1992) and Blommers-Schlösser (1993), the Ranidae consists of about 12 subfamilies (Fig. 1), of which five are endemic to Africa. Ranids are a paraphyletic group that, together with the Mantellidae and Rhacophoridae, forms the epifamily Ranoidae. These are hierarchically a fraction of the superfamily Ranoidea and the suborder Neobatrachia which both probably are monophyletic (Hoegg et al., 2004).

Sequences were obtained from taxa representing all ranid subfamilies except the Micrixalinae (Table 1), as well as from the families Mantellidae and Rhacophoridae. We furthermore included taxa belonging to the Arthroleptoidae and Microhyloidae. Latimeria, Homo, Gallus, the salamander Lyciasalamandra, two archaeobatrachians of the genus Alytes, and two hylid neobatrachians, genera Agalychnis and Litoria, as hierarchical outgroups (not shown in figures).

\subsection{DNA sequencing}

DNA was extracted from muscle or skin tissue fixed in $99 \%$ ethanol. Tissue samples were digested using proteinase $\mathrm{K}$ (final concentration $1 \mathrm{mg} / \mathrm{mL}$ ), homogenized and subsequently purified following a standard salt extraction protocol. Primers for rag-1 and rag-2 were from Hoegg et al. (2004) as reported in Chiari et al. (2004). Primers for one fragment of the $12 \mathrm{~S}$ rRNA gene and one fragment of the 16S rRNA gene were 12SA-L and 12SB-H and 16SA-L and 16SB-H of Palumbi et al. (1991), respectively (see Vences et al., 2003a). Primers for a fragment of rhodopsin exon (Rhod1A and Rhod1D) were from Bossuyt and Milinkovitch (2000). PCR was performed in $25 \mu 1$ reactions containing $0.5-1.0 \mathrm{U}$ of REDTaq DNA Polymerase (Sigma, Taufkirchen, Germany), $0.01 \mathrm{U}$ of Pwo DNA polymerase (Roche, Mannheim, Germany), 50 ng genomic DNA, $10 \mathrm{pmol}$ of each primer, $15 \mathrm{nmol}$ of each dNTP, $50 \mathrm{nmol}$ additional $\mathrm{MgCl}_{2}$, and the REDTaq PCR buffer (in final reaction solution: $10 \mathrm{mM}$ Tris$\mathrm{HCl}, \mathrm{pH} 8.3,50 \mathrm{mM} \mathrm{KCl}, 1.1 \mathrm{mM} \mathrm{MgCl}_{2}$, and $0.01 \%$ gelatine). For rag-1 and rag-2 cycle conditions were adapted from a long range PCR protocol (Barnes, 1994), with an initial denaturation step at $94^{\circ} \mathrm{C}$ for $5 \mathrm{~min}$, followed by 10 cycles with $94^{\circ} \mathrm{C}$ for $30 \mathrm{~s}$, annealing temperatures increasing by $0.5^{\circ} \mathrm{C}$ per cycle from 52 to $57^{\circ} \mathrm{C}$ and extending for $3 \mathrm{~min}$ at $68^{\circ} \mathrm{C}$. Additionally, 20 cycles were performed with $94^{\circ} \mathrm{C}$ for $10 \mathrm{~s}, 57^{\circ} \mathrm{C}$ for $40 \mathrm{~s}$, and $68^{\circ} \mathrm{C}$ for $3 \mathrm{~min}$. The final extension was done at $68^{\circ} \mathrm{C}$ for $5 \mathrm{~min}$. For $12 \mathrm{~S}$ and $16 \mathrm{~S}$ the denaturation step was followed by 35 cycles of denaturation at $94^{\circ} \mathrm{C}$ for $30 \mathrm{~s}$, annealing at $50^{\circ} \mathrm{C}$ for $30 \mathrm{~s}$, and extension at $72{ }^{\circ} \mathrm{C}$ for $90 \mathrm{~s}$.

PCR products were purified via spin columns (Qiagen). Sequencing was performed directly using the corresponding PCR primers (forward and reverse). DNA sequences of both strands were obtained using the BigDye Terminator cycle-sequencing ready reaction kit (Applied Biosystems) on an ABI 3100 capillary sequencer using the manufacturer's instructions. New sequences for 37 species were combined with existing sequences taken from GenBank in the final dataset. These sequences were deposited in GenBank (for accession numbers see Table 1).

\subsection{Data analysis}

DNA sequences were aligned using ClustalW (Thompson et al., 1994). Gapped and hypervariable sites, totalling 729 characters, were excluded from the analyses. A homogeneity partition test (Farris et al., 1994) as implemented in PAUP* (Swofford, 2002) rejected homogeneity of the different markers. Besides a combined analysis of the combined dataset we therefore also performed separate analyses of the various genes.

The combined dataset was used to calculate neighbor- joining (NJ), maximum parsimony (MP), and maximum likelihood (ML) phylogenies using PAUP* (Swofford, 2002). Heuristic searches were performed using 10 replicates of a stepwise addition of taxa. The best fitting models of sequence evolution for ML analyses (Table 2) were determined by hierarchical likelihood ratio tests and by the AIC criterion in Modeltest 3.06 (Posada and Crandall, 1998). Bootstrap branch support values were calculated with 500 MP replicates and 100 ML replicates.

Bayesian inference (BI) of the combined and of separate datasets was conducted with MrBayes $3.0 \mathrm{~b} 4$ (Huelsenbeck and Ronquist, 2001), using models (Table 2) estimated with Modeltest under the AIC criterion, with 250,000 generations, sampling trees every 10th generation (and calculating a consensus tree after omitting the first 3000 trees). For the combined dataset, $1,000,000$ generations were computed, with a burn-in of 10,000 . These BI phylogeny reconstructions were repeated five times each, resulting in only very minor differences in the resulting trees, all referring to unsupported branches without relevance for the present study.

\subsection{Divergence time estimation}

We used the MultiDivTime package (Thorne and Kishino, 2002; Thorne et al., 1998) to estimate the divergence times, based on nuclear sequences only. Calibration 
Table 1

Voucher specimens and GenBank accession numbers of taxa studied

\begin{tabular}{|c|c|c|c|c|c|c|c|}
\hline \multirow[t]{2}{*}{ Species } & \multirow[t]{2}{*}{ Family } & \multirow{2}{*}{$\begin{array}{l}\text { Locality and voucher } \\
\text { specimen }\end{array}$} & \multicolumn{5}{|c|}{ Accession Nos. } \\
\hline & & & $12 \mathrm{~S}$ & $16 \mathrm{~S}$ & Rag-1 & Rag-2 & Rhodopsin \\
\hline Homo sapiens & Hominidae & GenBank & NC_001807 & NC_001807 & NM_000448 & ВC022397 & NM_000539 \\
\hline Latimeria sp. & Coelacanthidae & GenBank & Z21921 & Z21921 & AY 442925 & AF369087 & $\mathrm{AF} 131253$ \\
\hline Gallus gallus & Phasianidae & GenBank & AY235571 & AY235571 & AF143730 & M58531 & D00702 \\
\hline \multirow[t]{2}{*}{$\begin{array}{l}\text { Lyciasalamandra } \\
\text { luschani }\end{array}$} & Salamandridae & GenBank & AF154053 & AF154053 & AY323753 & AY323797 & $\mathrm{U} 36574^{*}$ \\
\hline & & & - & - & - & - & - \\
\hline Alytes dickhilleni & Discoglossidae & $\begin{array}{l}\text { Parejo, Spain } \\
\text { (no voucher) }\end{array}$ & AY333672 & AY333710 & DQ019494 & DQ019517 & AY341817 \\
\hline Alytes muletensis & Discoglossidae & $\begin{array}{l}\text { Mallorca, Spain } \\
\text { (no voucher) }\end{array}$ & AY333671 & AF224729 & AY323755 & AY323781 & AY323731 \\
\hline Agalychnis callidryas & Hylidae & Pet trade (no voucher) & AY330898 & AY330890 & AY323765 & AY323780 & AY323750 \\
\hline Litoria caerulea & Hylidae & Pet trade (no voucher) & AY330903 & AY330894 & AY323767 & AY323793 & AY323751 \\
\hline Heterixalus tricolor & Hyperoliidae & $\begin{array}{l}\text { Madagascar, } \\
\text { ZSM 700/2001 }\end{array}$ & AF215434 & AF 215220 & AY323768 & AY323787 & AY323741 \\
\hline $\begin{array}{l}\text { Hyperolius } \\
\text { viridiflavus }\end{array}$ & Hyperoliidae & $\begin{array}{l}\text { Barberton, South Africa, } \\
\text { ZFMK } 66726\end{array}$ & AY330901 & AY323789 & AY323740 & AF215440 & AF215223 \\
\hline $\begin{array}{l}\text { Aglyptodactylus } \\
\quad \text { madagascariensis }\end{array}$ & Mantellidae & $\begin{array}{l}\text { Madagascar, } \\
\text { ZSM 183/2002 }\end{array}$ & AF215179 & AY341678 & AY571640 & DQ019516 & DQ019552 \\
\hline Boophis doulioti & Mantellidae & $\begin{array}{l}\text { Madagascar, } \\
\text { ZSM 185/2002 }\end{array}$ & AY341608 & AY341663 & AY571643 & DQ019519 & AY341792 \\
\hline Laliostoma labrosum & Mantellidae & $\begin{array}{l}\text { Madagascar, } \\
\text { UADBA-MV 2001.1466 }\end{array}$ & AF215178 & AY341679 & AY571652 & DQ019530 & AF249106 \\
\hline $\begin{array}{l}\text { Mantella } \\
\quad \text { madagascariensis }\end{array}$ & Mantellidae & Pet trade (no voucher) & AF124101 & AF124131 & DQ019500 & DQ019532 & AY263284 \\
\hline Mantidactylus sp. & Mantellidae & $\begin{array}{l}\text { Mayotte, } \\
\text { ZSM 652/2000 }\end{array}$ & AY330906 & AY330888 & AY323775 & AY323794 & AY323742 \\
\hline Mantidactylus wittei & Mantellidae & $\begin{array}{l}\text { Madagascar, } \\
\text { ZSM 405/2000 }\end{array}$ & AY330904 & AF317691 & AY323774 & AY323795 & AY323743 \\
\hline Breviceps fuscus & Microhylidae & $\begin{array}{l}\text { Big Tree, South Africa, } \\
\text { ZFMK } 66716\end{array}$ & DQ019578 & AF215366 & AY571644 & DQ019520 & DQ019553 \\
\hline Dyscophus antongilii & Microhylidae & $\begin{array}{l}\text { Maroantsetra, } \\
\text { Madagascar } \\
\text { (no voucher) }\end{array}$ & DQ019581 & DQ019601 & AY571648 & DQ019525 & DQ019558 \\
\hline Kaloula pulchra & Microhylidae & Pet trade (no voucher) & AY330902 & AY330893 & AY323772 & AY323790 & AF249100* \\
\hline $\begin{array}{l}\text { Plethodontohyla } \\
\text { alluaudi }\end{array}$ & Microhylidae & $\begin{array}{l}\text { Madagascar, } \\
\text { ZSM 3/2002 }\end{array}$ & DQ019589 & DQ019606 & AY571661 & DQ019541 & DQ019568 \\
\hline $\begin{array}{l}\text { Scaphiophryne } \\
\text { calcarata }\end{array}$ & Microhylidae & $\begin{array}{l}\text { Madagascar, } \\
\text { ZSM 115/2002 }\end{array}$ & DQ019593 & AJ314811 & AY571660 & DQ019548 & DQ019573 \\
\hline Afrana angolensis & Ranidae & $\begin{array}{l}\text { Barberton, South Africa } \\
\text { (no voucher) }\end{array}$ & DQ019576 & DQ019596 & DQ019493 & DQ019515 & DQ019551 \\
\hline $\begin{array}{l}\text { Amnirana } \\
\text { (Hylarana) lepus }\end{array}$ & Ranidae & $\begin{array}{l}\text { Cameroon, pet trade, } \\
\text { ZFMK } 64831\end{array}$ & DQ019584 & AY014377 & AY571641 & DQ019529 & DQ019561 \\
\hline Amolops hainanensis & Ranidae & $\begin{array}{l}\text { Hainan island, China, } \\
\text { MVZ } 230383\end{array}$ & DQ019577 & DQ019597 & DQ019495 & DQ019518 & AY $322231^{*}$ \\
\hline $\begin{array}{l}\text { Cacosternum } \\
\text { boettgeri }\end{array}$ & Ranidae & $\begin{array}{l}\text { Hardap, Namibia, } \\
\text { ZFMK } 66727\end{array}$ & AF124096 & AF215414 & AY571645 & DQ019521 & DQ019554 \\
\hline $\begin{array}{l}\text { Ceratobatrachus } \\
\text { guentheri }\end{array}$ & Ranidae & Pet trade (no voucher) & DQ019579 & DQ019598 & DQ019496 & DQ019522 & DQ019555 \\
\hline Conraua crassipes & Ranidae & $\begin{array}{l}\text { Nlonako, Cameroon, } \\
\text { ZFMK } 75446\end{array}$ & DQ019580 & DQ019600 & DQ019498 & DQ019524 & DQ019557 \\
\hline Fejervarya sp. & Ranidae & $\begin{array}{l}\text { ZFMK uncatalogued } \\
\text { (MV-PB11) }\end{array}$ & DQ019582 & DQ019602 & AY571649 & DQ019526 & DQ019559 \\
\hline $\begin{array}{l}\text { Hoplobatrachus } \\
\text { occipitalis }\end{array}$ & Ranidae & Voucher not collected & AJ564734 & AY341689 & AY571650 & DQ019527 & AJ564730 \\
\hline $\begin{array}{l}\text { Hylarana (Rana) } \\
\text { gracilis }\end{array}$ & Ranidae & $\begin{array}{l}\text { Belihuloya, Sri Lanka, } \\
\text { ZFMK } \\
\text { (MNHN 2000.614) }\end{array}$ & DQ019583 & AY014376 & DQ019499 & DQ019528 & DQ019560 \\
\hline Indirana sp. & Ranidae & $\begin{array}{l}\text { Indirana sp., several } \\
\text { different specimens }\end{array}$ & AF215194 & AF215392 & AF249122 & AF215194 & AF215391 \\
\hline $\begin{array}{l}\text { Lankanectes } \\
\text { corrugatus }\end{array}$ & Ranidae & $\begin{array}{l}\text { Kandy, Sri Lanka, } \\
\text { MNHN } 2000.616\end{array}$ & DQ019586 & DQ019603 & AY571653 & DQ019531 & DQ019562 \\
\hline
\end{tabular}


Table 1 (continued)

\begin{tabular}{|c|c|c|c|c|c|c|c|}
\hline \multirow[t]{2}{*}{ Species } & \multirow[t]{2}{*}{ Family } & \multirow{2}{*}{$\begin{array}{l}\text { Locality and voucher } \\
\text { specimen }\end{array}$} & \multicolumn{5}{|c|}{ Accession Nos. } \\
\hline & & & $12 \mathrm{~S}$ & $16 \mathrm{~S}$ & Rag-1 & Rag-2 & Rhodopsin \\
\hline Nanorana parkeri & Ranidae & $\begin{array}{l}\text { Sichuan Prov., China, } \\
\text { MVZ } 231206\end{array}$ & AF206110 & AY322283 & DQ019501 & DQ019533 & AY322219 \\
\hline $\begin{array}{l}\text { Natalobatrachus } \\
\text { bonebergi }\end{array}$ & Ranidae & $\begin{array}{l}\text { The Haven, South } \\
\text { Africa, ZFMK } 66443\end{array}$ & AF215198 & AF215396 & DQ019502 & DQ019534 & DQ019563 \\
\hline Nyctibatrachus major & Ranidae & $\begin{array}{l}\text { Ooty, India, ZFMK } \\
74837\end{array}$ & AF249017 & AY341687 & AY571655 & DQ019535 & AF249113 \\
\hline Occidozyga lima & Ranidae & $\begin{array}{l}\text { China, Hainan Prov., } \\
\text { MVZ } 236659\end{array}$ & AF161027 & AF 285213 & DQ019503 & DQ019536 & DQ019564 \\
\hline Paa verrucospinosa & Ranidae & $\begin{array}{l}\text { Vietnam, Vinh Phu } \\
\text { Prov., MVZ } 223858\end{array}$ & AF205552 & AY322284 & DQ019504 & DQ019537 & AY322234* \\
\hline Petropedetes parkeri & Ranidae & $\begin{array}{l}\text { Cameroon, Voucher } \\
\text { not collected }\end{array}$ & AY341628 & AF124132 & DQ019505 & DQ019538 & AY341813 \\
\hline $\begin{array}{l}\text { Phrynobatrachus } \\
\text { natalensis }\end{array}$ & Ranidae & $\begin{array}{l}\text { Mtunzini, South } \\
\text { Africa, ZFMK } 73452\end{array}$ & DQ019588 & DQ019605 & DQ019507 & DQ019540 & DQ019567 \\
\hline $\begin{array}{l}\text { Ptychadena } \\
\quad \text { mascareniensis }\end{array}$ & Ranidae & $\begin{array}{l}\text { Madagascar, ZSM } \\
\text { 190/2002 }\end{array}$ & AY341624 & AY341690 & AY571658 & DQ019542 & AY341809 \\
\hline $\begin{array}{l}\text { Pyxicephalus } \\
\text { adspersus }\end{array}$ & Ranidae & $\begin{array}{l}\text { Rundu, Namibia (no } \\
\text { voucher) }\end{array}$ & AF206091 & AF215505 & DQ019508 & DQ019543 & DQ019569 \\
\hline Rana aurora & Ranidae & $\begin{array}{l}\text { Del Norte co., CA, } \\
\text { USA, MVZ } 188965\end{array}$ & DQ019590 & DQ019607 & DQ019509 & DQ019544 & DQ019570 \\
\hline Rana berlandieri & Ranidae & $\begin{array}{l}\text { Mexico, Coahuila, } \\
\text { MVZ } 145474\end{array}$ & AY115111 & DQ019608 & DQ019510 & DQ019545 & DQ019571 \\
\hline Rana sylvatica & Ranidae & $\begin{array}{l}\text { Tompkins co., NY, } \\
\text { USA, MVZ } 137426\end{array}$ & DQ019591 & AF175977 & DQ019511 & DQ019546 & DQ019572 \\
\hline Rana temporaria & Ranidae & voucher not collected & AF124103 & AF124135 & AY323776 & AY323803 & AF249119 \\
\hline $\begin{array}{l}\text { Strongylopus } \\
\text { fasciatus }\end{array}$ & Ranidae & $\begin{array}{l}\text { Little Brak, South } \\
\text { Africa, ZFMK } 66444\end{array}$ & DQ019594 & AF215412 & DQ019513 & DQ019549 & DQ019574 \\
\hline $\begin{array}{l}\text { Tomopterna sp. } \\
\text { "Khorixas" }\end{array}$ & Ranidae & $\begin{array}{l}\text { Khorixas, Namibia, } \\
\text { ZFMK } 66403\end{array}$ & DQ019595 & DQ019610 & DQ019514 & DQ019550 & DQ019575 \\
\hline $\begin{array}{l}\text { Chirixalus cf. } \\
\text { Vittatus }\end{array}$ & Rhacophoridae & $\begin{array}{l}\text { Myanmar, pet trade, } \\
\text { ZFMK } 65463\end{array}$ & AF458131 & AF215346 & AY571646 & DQ019523 & DQ019556 \\
\hline $\begin{array}{l}\text { Philautus cf. } \\
\text { Macropus }\end{array}$ & Rhacophoridae & $\begin{array}{l}\text { Belihuloya, Sri Lanka } \\
\text { (no voucher) }\end{array}$ & DQ019587 & DQ019604 & DQ019506 & DQ019539 & DQ019566 \\
\hline $\begin{array}{l}\text { Polypedates } \\
\text { maculatus }\end{array}$ & Rhacophoridae & voucher not collected & AF215184 & AF215358 & AY323777 & AY323802 & AF249124* \\
\hline Rhacophorus dennysii & Rhacophoridae & $\begin{array}{l}\text { Pet trade, ZFMK } \\
65461\end{array}$ & DQ019592 & DQ019609 & AY571659 & DQ019547 & AF249125* \\
\hline
\end{tabular}

Localities and voucher specimens refer to sequences obtained in this study; some other sequences from GenBank refer to other conspecific individuals. Collection acronyms are as follows: MNHN-Muséum National d'Histoire Naturelle, Paris, France; MVZ—Museum of Vertebrate Zoology, University of California at Berkeley, USA; UADBA_-Université d'Antananarivo, Département de Biologie Animale, Madagascar, numbers being field numbers of M. Vences of specimens deposited in UADBA; ZFMK - Zoologisches Forschungsinstitut und Museum A. Koenig, Bonn, Germany; ZSM-Zoologische Staatssammlung München, Germany. Accession numbers marked with an asterisk indicate sequences of congeneric species, except for Lyciasalamandra which we combined with a rhodopsin sequence of a different salamander genus, Ambystoma.

points were applied as follows: (1) minimum age of the frogs-salamander split at 230 mya (fossil record of frog ancestor Triadobatrachus; (Sanchiz, 1998)); (2) minimum age of the split between Agalychnis and Litoria at 42 mya (last connection between Australia and South America; (Seddon et al., 1998)); (3) maximum age of the split between Mantidactylus wittei and Mantidactylus sp. from the Comoro islands at 15 mya (volcanic origin of the oldest Comoro island Mayotte; (Vences et al., 2003b)); (4) minimum age of the Alytes muletensisAlytes dickhillenii split at 5 mya (Mediterranean salinity crisis; Fromhage et al., 2004); and (5) age interval of the split between diapsids and synapsids at 338-288 mya (Graur and Martin, 2004).

\section{Results}

After exclusion of highly variable regions of $12 \mathrm{~S}$ and 16S rRNA, the concatenated dataset consisted of 2995 nucleotides from nuclear genes (rag-1, rag-2, and rhodopsin) and mitochondrial genes (12S and 16S). Of these, 318 nucleotides were uninformative and 1212 base pairs were parsimony informative. For rag-1 606 sites were parsimony informative and 589 were constant of a total of 1330 sequenced nucleotides. For rag-2 755 base pairs were sequenced and contained 472 informative and 219 constant sites. Rhodopsin had 127 informative and 134 constant of a total of 289 characters. The fragments of the mitochondrial genes $12 \mathrm{~S}$ and $16 \mathrm{~S}$ had 119 and 141 


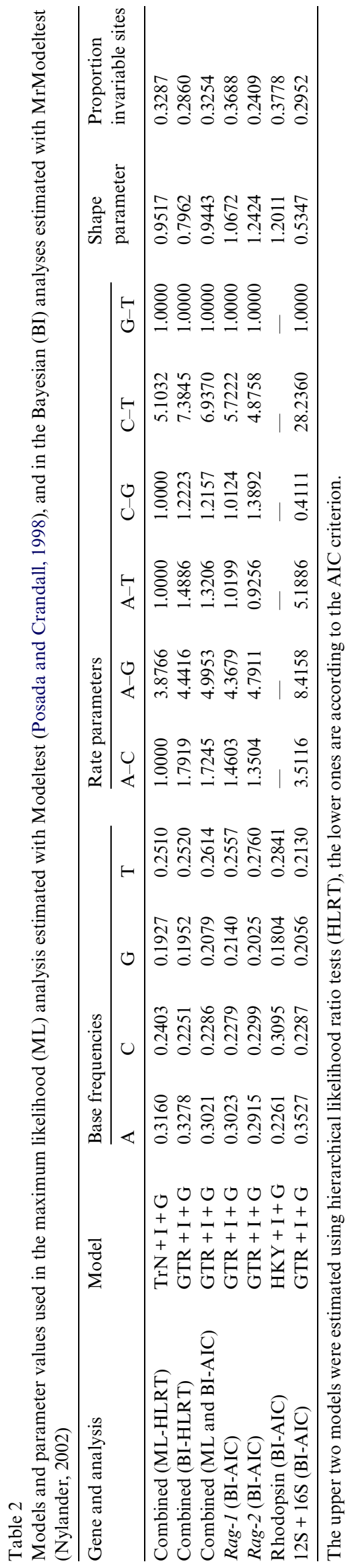

informative, and 82 and 188 constant of 253 and 368 characters, respectively. None of the nuclear gene fragments showed saturation when transitions and transversions were plotted against sequence divergence. All the phylogenies based on the combined dataset resolved the hierarchical outgroups in the expected relationships.

The phylogenies based on the combined dataset obtained through MP, NJ, and ML consistently show the superfamily Ranoidea as a clade with high bootstrap support (Fig. 2), containing the included representatives of Ranoidae, Microhyloidae, and Arthroleptoidae (support values from MP bootstrap and ML bootstrap; $100 \%$ and BI analysis $98 \%$ ). The clustering of Breviceps with the hyperoliids $(82,62$, and 100$)$ provides further support for the exclusion of this genus from the Microhylidae, as already indicated in an earlier study using only rag-1 (Van der Meijden et al., 2004). A more inclusive arthroleptoid sampling including the Hemisotidae is necessary to determine the position of Breviceps and related genera, since the Hemisotidae were found to be closely related to the hyperoliids (Biju and Bossuyt, 2003).

The clade Ranoidae receives high support (100, 97, and 100 ), as do several subclades within this epifamily that agree with current classification. This pertains to the Rhacophoridae, Mantellidae, Dicroglossinae, and Raninae. Basal resolution within the Ranoidae epifamily is low, however. The nested position of the Rhacophoridae and Mantellidae renders the Ranidae paraphyletic. The position of the platymantine Ceratobatrachus is inconsistent between the different methods of analysis and remains only weakly resolved, indicating that the subfamily Platymantinae is distinct from other ranoids. The relationships of the African genera Phrynobatrachus and Ptychadena to the remaining Ranoidae could not be resolved unambiguously. Excluding these two genera and a further clade of African species (see below), the remaining Eurasian and American Ranoidae form a monophyletic clade with some, albeit low, support $(<50,60$, and 100). The African species Hoplobatrachus occipitalis and Amnirana lepus are nested within the largely Asian Dicroglossinae and Raninae, supporting the hypothesis of their Asian origin (Kosuch et al., 2001).

Most remarkable is the presence of a highly supported clade $(100,94$, and 100) containing representatives of six sub-Saharan genera, most of which have so far not been considered to be related (Fig. 2): Afrana, Cacosternum, Natalobatrachus, Pyxicephalus, Strongylopus and Tomopterna. Biogeographically, the center of diversity and endemism of this divergent set of taxa is in southernmost Africa (Fig. 4). This endemic southern African clade is highly distinct and supported irrespective of the type of phylogenetic analysis. Further African genera such as Petropedetes and Conraua may be among its basal representatives (Fig. 2) but support for this placement is weak and they are thus not considered further here. The clade is resolved, at least partially, also in separate Bayesian analyses of the gene fragments used (Fig. 3). rag- 1 and $\mathrm{rag}-2$ were congruent in strongly supporting a 


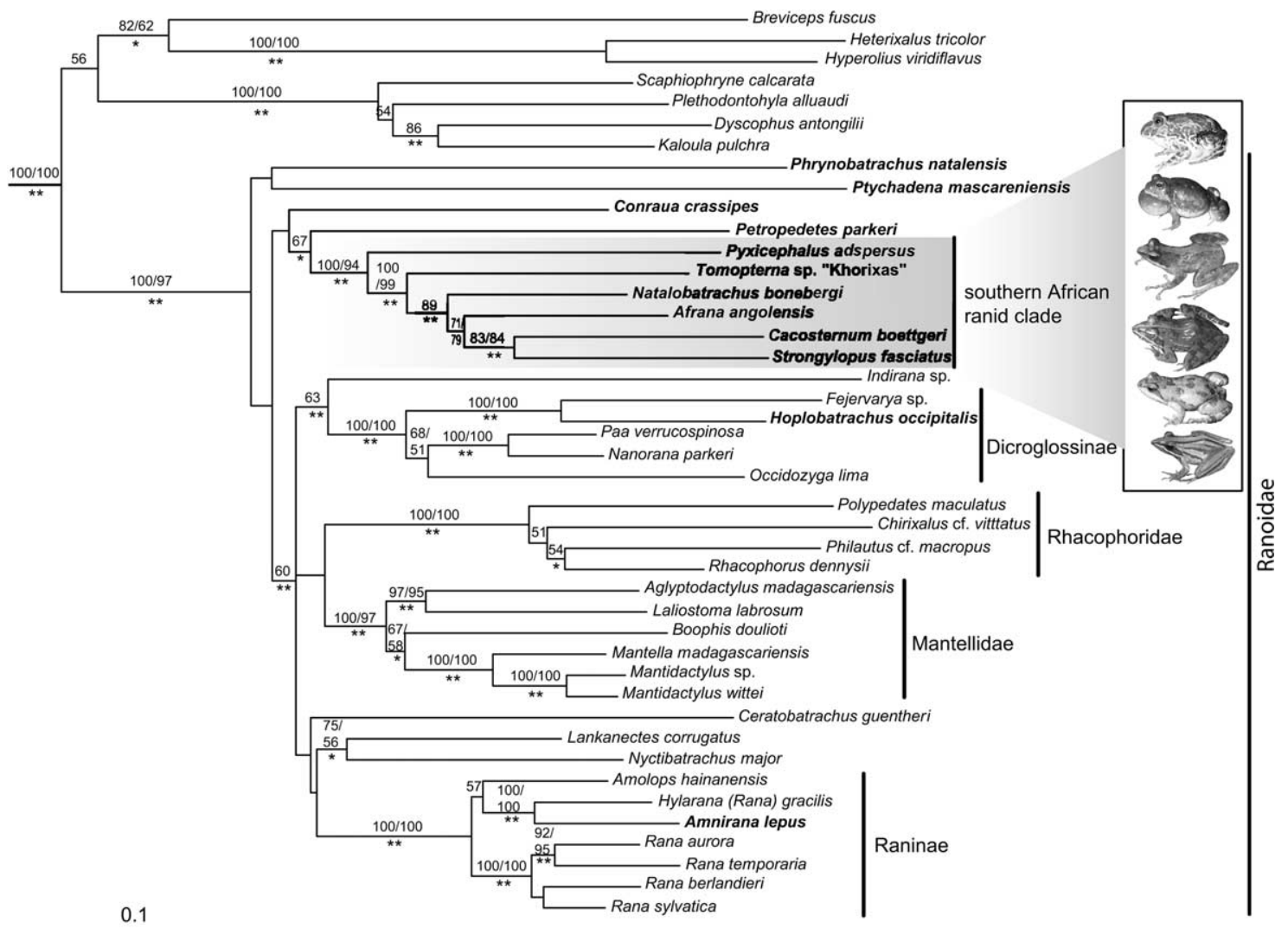

Fig. 2. Maximum likelihood phylogram of the superfamily Ranoidea, rooted with hierarchical outgroups Latimeria, Homo, Gallus, Lyciasalamandra, Alytes, Agalychnis, and Litoria (not shown), based on the combined dataset of nuclear and mitochondrial sequences. Support values above branches are ML/MP bootstrap values, a single asterisk below a branch indicates a Bayesian posterior probability above $95 \%$, and two asterisks indicate a Bayesian posterior probability of $100 \%$. When only one value is shown it refers to the ML support (the MP support in these cases was below $50 \%$ ). This tree was obtained using a substitution model suggested by hierarchical likelihood ratio tests; a tree calculated under the substitution model suggested by the AIC criterion in Modeltest (Posada and Crandall, 1998) was identical except in placing Ceratobatrachus sister to rhacophorids. African Ranoidae are marked in bold. Inset shows the diversity of the representatives of the endemic African clade, in order from top to bottom Pyxicephalus adspersus, Tomopterna sp. (Khorixas), Natalobatrachus bonebergi, Afrana angolensis, Cacosternum boettgeri, and Strongylopus fasciatus.

monophyletic group of all six taxa, whereas rhodopsin supported a group of only five of them (excluding Afrana), and $12 \mathrm{~S}+16 \mathrm{~S}$ included, in addition, Petropedetes and Phrynobatrachus in this clade (although with conspicuously long branches, indicative of a possibly spurious placement).

Bayesian analysis of divergence times (Table 3) provided a posterior age estimate of the epifamily Ranoidae of 91.9 mya (95\% confidence intervals 65.9-124.4 mya), of the endemic ranid clade with Pyxicephalus as the most basal taxon of 69.9 (48.9-96.5) mya and of the more inclusive clade with also Petropedetes and Conrana of 85.6 (61.1-116.4) mya.

\section{Discussion}

\subsection{Endemic ranids from Southern Africa form an unexpected novel and divergent clade}

With over 200 species of ranids found only in Africa, it is, after Asia, the continent with the second highest species diversity of this family. Most of these species have never been included in global phylogenetic studies. Several thorough osteological studies on African taxa (e.g., Clarke, 1981; Deckert, 1938) included no or very few Asian taxa whereas most of the recent molecular studies on ranids (Bossuyt and Milinkovitch, 2000; Emerson et al., 2000a; Marmayou et al., 2000; Roelants et al., 2004) focused on Asian taxa.

Despite this relative lack of knowledge, the finding of a highly supported Southern African ranid clade in our analysis was still most surprising. The phylogenetic relationships implied by Fig. 2 have not been previously hypothesized based on morphological data (e.g., Clarke, 1981). This clade, with Pyxicephalus basal to the other five genera, is strongly supported by the combined analysis and by separate analyses of rag-l and rag-2. Phylogenies based on rhodopsin, and on the mitochondrial $12 \mathrm{~S}$ and $16 \mathrm{~S}$ rRNA, provide some additional support for close relationships of taxa in this clade in the combined analyses but are less unequivocal when analysed individually (Fig. 3). However, the low 
RAG-1

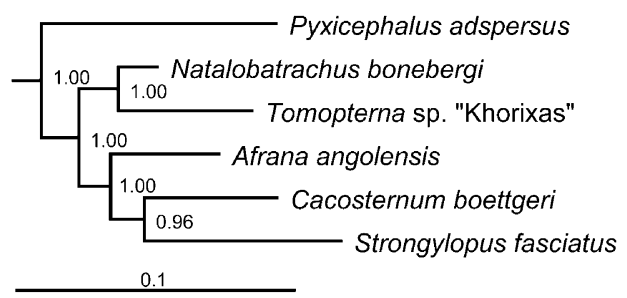

Rhodopsin

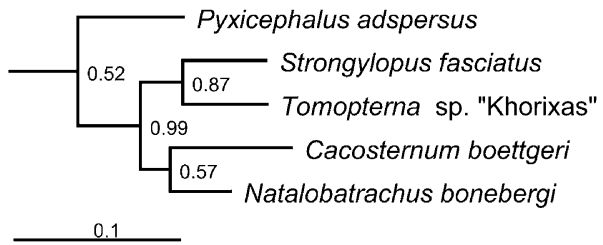

RAG-2

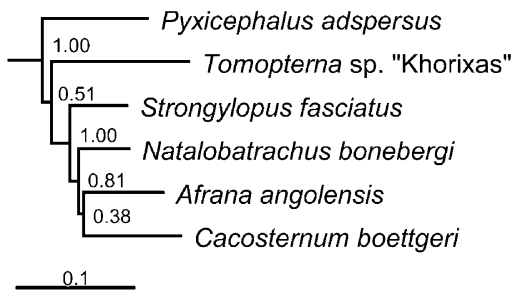

$12 \mathrm{~S}$ and $16 \mathrm{~S}$

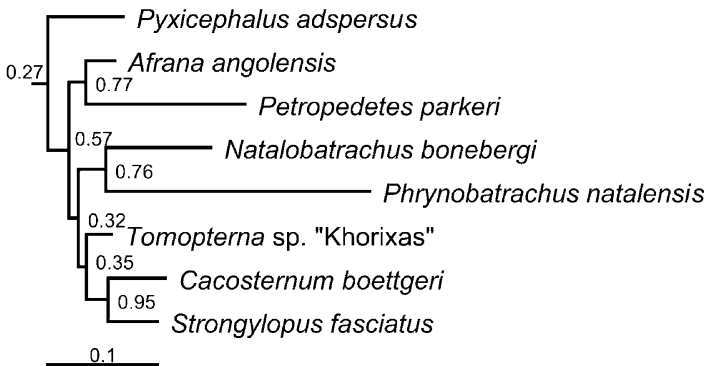

Fig. 3. Separate Bayesian trees of the gene fragments. Mitochondrial markers (12S and 16S rRNA fragments) were combined in a single dataset. Numbers are posterior probabilities.

Table 3

Posterior time estimates of most relevant splits within the Ranoidea from a Bayesian analysis using the MultiDivTime program (Thorne and Kishino, 2002) with calibrations and settings given in Section 2

\begin{tabular}{lccc}
\hline Clade & Age (MY) & Standard deviation & $\begin{array}{c}95 \% \text { confidence } \\
\text { interval }\end{array}$ \\
\hline Ranoidea & 133.6 & 19.8 & $99.2-176.7$ \\
Arthroleptoidae-Microhylidae & 127.1 & 19.4 & $93.2-169.4$ \\
Ranoidae & 91.9 & 14.9 & $65.9-124.4$ \\
African endemic clade + Conraua + Petropedetes & 85.6 & 14.1 & $61.1-116.4$ \\
Non-African Ranoidae including Amnirana, & 83.3 & 13.7 & $59.4-113.2$ \\
$\quad$ Hoplobatrachus, and Chirixalus & & & $58.0-111.6$ \\
African endemic clade + Petropedetes & 81.7 & 13.7 & $51.6-100.1$ \\
Mantellidae + Rhacophoridae & 73.1 & 12.4 & $48.9-96.5$ \\
African endemic clade & 69.9 & 12.3 & $42.7-86.0$ \\
African endemic clade excluding Pyxicephalus & 61.7 & 11.3 & $40.7-80.5$ \\
Mantellidae & 58.2 & 10.2 & $34.1-71.8$ \\
Natalobatrachus, Afrana, Cacosternum, Strongylopus & 50.4 & 9.7 & $31.9-68.0$ \\
Afrana, Cacosternum, Strongylopus & 47.7 & 9.3 & 2.9 \\
Cacosternum, Strongylopus & 40.2 & 8.4 & 23.9 \\
Rhacophoridae & 36.0 & 7.5 & 2.9 \\
Raninae (excluding Afrana) & 33.9 & 7.5 & \\
& & & \\
\end{tabular}

phylogenetic resolution of the latter three genes is not surprising because (a) for rhodopsin, we only included a short fragment (289 bp), and (b) and for mitochondrial genes such as $12 \mathrm{~S}$ and $16 \mathrm{~S}$ it is known that they are less informative in resolving deep phylogenetic relationships compared to single-copy protein coding nuclear genes (e.g., Springer et al., 2001).

One of the six genera unambiguously included in the endemic southern African clade, Natalobatrachus, is classified in the Petropedetinae (Blommers-Schlösser, 1993; considered as the family Phrynobatrachidae by Dubois, 1992) mainly based on osteological and dental characters (Laurent, 1986). Cacosternum has been placed in the Cacosterninae (Blommers-Schlösser, 1993). Afrana and Strongylopus have been classified in the Raninae, Tomopterna and Pyxicephalus in the Tomopterninae and Pyxicephalinae, respectively (Blommers-Schlösser, 1993; Dubois, 1992). While the Cacosterninae, Pyxicephalinae and Tomopterninae may belong to the endemic African clade in their totality (except for the Asian Nannophrys that was placed in the Cacosterninae by Blommers-Schlösser, 1993), this is not the case for the Petropedetinae and Raninae. Indeed, the Raninae included here form a well-defined clade when Strongylopus and Afrana, considered subgenera of Rana by Dubois (1992), are excluded (Fig. 2). 
The elusion of this molecularly well-distinguishable endemic southern African clade of ranids to morphological analyses suggests a high incidence of homoplasy in morphological characters used for their classification. Other regional radiations, such as the Madagascan and Indian tree frogs (Bossuyt and Milinkovitch, 2000), or Indian and African burrowing frogs (Biju and Bossuyt, 2003) show a similar pattern of morphological homoplasy. In other ranoid frogs such as microhylids (Wild, 1995) and brevicipitines (Blommers-Schlösser, 1993; van der Meijden et al., 2004) homoplasy occurs in morphological characters as well. Alternatively, the placement of these taxa into separate subfamilies could have been be due to the lesser amount of attention that this large and highly diverse African ranid fauna has received relative to the other ranids, and therefore an artefact of observation. The genera in the endemic southern African clade were not only considered to belong to five different subfamilies or families, they also are morphologically and ecologically most distinct. Cacosternum are small frogs of generalized ecology and reproductive biology, many Tomopterna are burrowing savanna-dwelling frogs, Afrana are generalized semi-aquatic frogs, Natalobatrachus bonebergi is a semi-arboreal species living along rainforest streams, and Pyxicephalus are giant bullfrogs possessing fang- like projections of the lower jaw and a complex parental care behaviour. The genus Anhydrophryne is also likely to belong to this clade based on previously published mitochondrial data (Vences et al., 2000). These hogsback frogs live in humid South African forests and have direct development (Channing, 2001). Other South African genera of the Cacosterninae probably belong to the endemic southern African clade as well, although molecular data are lacking so far (see caption to Fig. 4) which would further increase the ecological diversity in this lineage.

The trend of species-richness of the southern African clade (Fig. 4) does not match the distribution of the total amphibian diversity, which tends to be highest in the humid region around Cameroon and an area covering Zambia, Mozambique, Tanzania and the Southeast of the Democratic Republic of the Congo (Stuart et al., 2004). Some species and genera of the African endemic clade (especially Pyxicephalus and Tomopterna) have succeeded in colonizing vast savanna areas of Africa, but other genera in this clade are restricted to Southern Africa, such as Natalobatrachus and Anhydrophryne. On the contrary, there is no genus in the clade restricted to any other region of Africa. This suggests that these frogs originated in this region and some lineages subsequently radiated across sub-Saharan
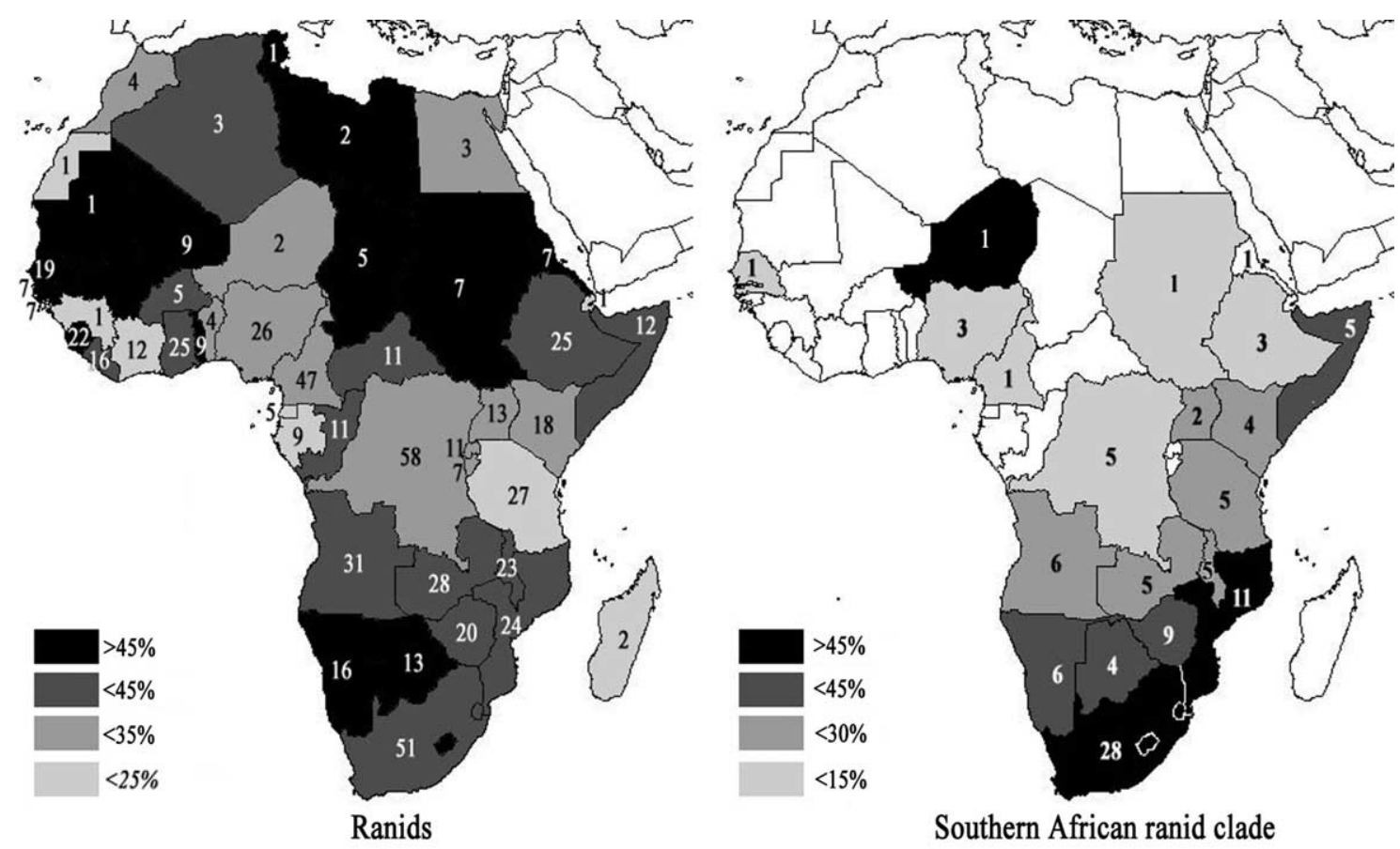

Fig. 4. Left map shows percentages of all ranid species as part of the total frog species numbers per country, with absolute number of ranids in each country (data from AmphibiaWeb.org). ${ }^{2}$ Percentage of the ranid species belonging to the endemic Southern African clade of the total ranid species count is shown on the right. Numbers represent absolute species numbers of frogs from the endemic Southern African clade. Frogs occurring in Lesotho and Swaziland were included in the South African species counts. The analysis considered all representatives demonstrated to belong to the Southern African clade herein (Fig. 2) and the genus Anhydrophryne that was closely related to Cacosternum in the molecular study of Vences et al. (2000). Inclusion of the other African cacosternine genera (Arthroleptella, Microbatrachella, Poyntonia, and Nothophryne (Blommers-Schlösser, 1993; Dubois, 2003)) would lead to an even stronger diversity hotspot in South Africa. 
Africa. The large range in biology and ecology suggest an adaptive radiation in these frogs similar to that of the Leptodactylidae in South America.

South Africa has a high endemism for flora, as it has the entire Cape Floristic Region within its borders (Mittermeier et al., 1998). The degree of endemism for amphibians is also spectacularly high; $54 \%$ of the 118 frogs that occur in South Africa are only found there. Of the 51 ranids that occur there, $27(53 \%)$ are endemic (calculated using data from AmphibiaWeb.org). ${ }^{2}$ Conservation International has marked the Cape Floristic Region as one of the world's biodiversity hotspots with 5682 endemic plant species and 53 endemic vertebrates (Myers et al., 2000). Future data will allow testing possible biogeographic correlates between the high floral endemism of the Cape Floristic Region and the southern African diversity hotspot of the endemic ranid clade identified herein. An entire radiation at the family level associated to some degree with the Cape Floral region will further strengthen its status as a biodiversity hotspot, and can possibly serve as a flagship example of endemic biodiversity.

\subsection{Endemic African ranids are phylogenetically basal}

Despite the inclusion of almost $3 \mathrm{kbp}$ sequence data into our analysis, basal relationships among major ranoid clades remained largely unsolved. The lack of resolution basal within the Ranoidae, in contrast to the good resolution at levels below and above, could be a 'hard' polytomy caused by a relatively rapid radiation of the Ranidae. Alternatively, this pattern could be alleviated by the inclusion of more species. Independent from the uncertainty of their precise phylogenetic position, various species had high genetic divergences from all other taxa included. This applies to the African Petropedetes, Ptychadena, Phrynobatrachus, and Conraua, but also to the Asian Ceratobatrachus, a Solomon and Bourgainville island representative of platymantines that are endemic to the Philippines, Papua New Guinea, the Moluccas, New Britain, Admiralty, Solomon, and Fiji islands. The long branches of these taxa (Fig. 2) are indicative of long independent evolutionary histories. The age of their splits from their closest relatives were estimated between 92 and 86 mya (Table 3). As predicted by Roelants et al. (2004) the inclusion of these taxa leads to the identification of areas of endemism for deep evolutionary ranid lineages in addition to South Asia, namely the Philippine and Pacific region, and southern and central Africa.

The long isolation of Africa subsequent to Gondwana fragmentation has, similar to the faunal histories of South America and Australia, allowed for the

\footnotetext{
${ }^{2}$ Although the data in the AmphibiaWeb.org database is incomplete regarding African ranids awaiting an update with findings from the Global Amphibian Assessment, the general picture and the identified hotspots for the endemic clade are unlikely to change.
}

development of a unique endemic mammalian radiation: the Afrotheria (Murphy et al., 2001). This radiation includes a range of animals as dissimilar as elephants, aardvarks and golden moles. The time of the onset of the Afrotheria radiation has been estimated to be 79.9 mya, with $95 \%$ confidence intervals of 73.0-85.8 mya, by Springer et al. (2003). Bayesian analysis of the divergence time of the endemic ranid clade with Pyxicephalus as the most basal taxon provided an estimate of 69.9 (48.996.5) mya. Divergence time of the clade including Petropedetes and Conraua is 85.6 (61.1-116.4) mya (Table 3). This indicates that the radiation of the endemic African ranid clade may have occurred roughly in the same period as the Afrotherian radiation, although the large confidence intervals of our estimates inhibit more precise interpretations. This endemic clade and the other deep African lineages identified in our study, therefore contain a large amount of evolutionary history. This should be taken into consideration when outlining conservation strategies. In fact, in South Africa, Lesotho and Swaziland (Minter et al., 2004), 30\% (11 out of 37) species belonging to the endemic African clade (if cacosternines are considered as belonging to it entirely) are in a threatened red list category, while this applies to only $18 \%$ (14 out of 78 ) of the remaining frog species. This might be seen as indication for non-random extinction processes.

\section{Conclusion}

The amphibian decline problem and the persistent elusiveness of its causes highlight the limits of our knowledge of amphibian biodiversity and emphasize the urgency of the need for further studies to design informed conservation measures. The discovery of a clade that is supported by several independent nuclear as well as mitochondrial markers, but which has eluded workers using morphological characters, is indicative of the need of a well-resolved molecular phylogeny of amphibians. Possibly, high levels of phenotypic homoplasy so far hindered the discovery of reliable morphology-based phylogenetic relationships, especially of the ranoids. Clearly, further studies are necessary to investigate the characters that are particularly homoplasious. The uncovered endemic clade may be affected more strongly than others by declines, thereby stressing the importance of a phylogenetic framework for effective conservation priority assessment.

\section{Acknowledgments}

We are grateful to Carla Cicero, curator of the collections at the Museum of Vertebrate Zoology in Berkeley for granting tissue loans of several species (Tissue loan \# 6205). Alan Channing and Marius Burger assisted dur- 
ing fieldwork. We thank Ylenia Chiari, Dirk Steinke, David B. Wake and two anonymous reviewers for comments on the manuscript. This work was supported by grants of the Deutsche Forschungsgemeinschaft to A.M. and M.V.

\section{References}

AmphibiaWeb: Information on amphibian biology and conservation. [web application], 2004. Berkeley, California: AmphibiaWeb. Available from: <http://amphibiaweb.org.> (Accessed: 2004)

Barnes, W.M., 1994. PCR amplification of up to $35 \mathrm{~kb}$ DNA with high fidelity and high yield from $\lambda$ bacteriophage templates. Proc. Natl. Acad. Sci. USA 91, 2216-2220.

Biju, S.D., Bossuyt, F., 2003. New frog family from India reveals an ancient biogeographical link with the Seychelles. Nature 425, 711-714.

Blommers-Schlösser, R.M.A., 1993. Systematic relationships of the Mantellinae Laurent 1946 (Anura Ranoidea). Ethol. Ecol. Evol. 5, 199-218.

Bossuyt, F., Milinkovitch, M.C., 2000. Convergent adaptive radiations in Madagascan and Asian ranid frogs reveal covariation between larval and adult traits. Proc. Natl. Acad. Sci. USA 97, $6585-6590$.

Bossuyt, F., Milinkovitch, M.C., 2001. Amphibians as indicators of Early Tertiary "Out of India" dispersal of vertebrates. Science 292, 93-95.

Briggs, J.C., 2003. The biogeographic and tectonic history of India. J. Biogeogr. 30, 381-388.

Channing, A., 2001. Amphibians of Central and Southern Africa. Cornell University Press, Ithaca.

Chiari, Y., Vences, M., Vieites, D.R., Rabemananjara, F., Bora, P., Ramilijaona Ravoahangimalala, O., Meyer, A., 2004. New evidence for parallel evolution of colour patterns in Malagasy poison frogs (Mantella). Mol. Ecol. 13, 3763-3774.

Clarke, B., 1981. Comparative osteology and evolutionary relationships in the African Raninae (Anura Ranidae). Monit. Zool. Ital. (N.S.) 15 (Suppl.), 285-331.

Deckert, K., 1938. Beiträge zur Osteologie und Systematik ranider Froschlurche. Sber. Ges. Naturf. Freunde Berlin, 127-184

Dubois, A., 1992. Notes sur la classification des Ranidae (Amphibiens, Anoures). Bull. Soc. Linn. Lyon 61, 305-352.

Dubois, A., 2003. True frogs (Ranidae). In: Hutchins, M., Duellman, W.E., Schlager, N. (Eds.), Grzimek's Animal Life Encyclopedia, second ed. Amphibians. Gale Group, vol. 6, Farmington Hill, Michigan, pp. 245-264.

Dubois, A., Ohler, A., 2001. A new genus for an aquatic ranid (Amphibia, Anura) from Sri Lanka. Alytes 19, 81-106.

Duellman, W.E., Trueb, L., 1986. Biology of Amphibians. McGrawHill, New York.

Emerson, S.B., Inger, R.F., Iskandar, D., 2000a. Molecular systematics and biogeography of the fanged frogs of Southeast Asia. Mol. Phylogenet. Evol. 16, 131-142.

Emerson, S.B., Richards, C., Drewes, R.C., Kjer, K.M., 2000b. On the relationships among ranoid frogs: a review of the evidence. Herpetologica 56, 209-230.

Farris, J.S., Källersjö, M., Kluge, A.G., Bult, C., 1994. Testing significance of incongruence. Cladistics 10, 315-319.

Feller, A.E., Hedges, S.B., 1998. Molecular evidence for the early history of living amphibians. Mol. Phylogenet. Evol. 9, 509-516.

Fromhage, L., Vences, M., Veith, M., 2004. Testing alternative vicariance scenarios in Western Mediterranean discoglossid frogs. Mol. Phylogenet. Evol. 31, 308-322.

Graur, M., Martin, W., 2004. Reading the entrails of chickens: molecular timescales of evolution and the illusion of precision. Trends Genet. 20, 80-86.
Hedges, S.B., Hass, C.A., Maxson, L.R., 1992. Caribbean biogeography: molecular evidence for dispersal in West Indian terrestrial vertebrates. Proc. Natl. Acad. Sci. USA 89, 1909-1913.

Hoegg, S., Vences, M., Brinkmann, H., Meyer, A., 2004. Phylogeny and comparative substitution rates of frogs inferred from sequences of three nuclear genes. Mol. Biol. Evol. 21, 1188-1200.

Huelsenbeck, J.P., Ronquist, F., 2001. MRBAYES: Bayesian inference of phylogenetic trees. Bioinformatics 17, 754-755.

Kosuch, J., Vences, M., Dubois, A., Ohler, A., Böhme, W., 2001. Out of Asia: mitochondrial DNA evidence for an Oriental origin of tiger frogs, genus Hoplobatrachus. Mol. Phylogenet. Evol. 21, 398-407.

Laurent, R.F., 1986. Sous classe des lissamphibiens. Systématique. In: Grassé, P.P., Delsol M. (Eds.), Traité de Zoologie, Tome 14, 1B. Masson, Paris, pp. 594-797

Lötters, S., La Marca, E., Stuart, S., Gagliardo, R., Veith, M., 2004. A new dimension of current biodiversity loss? Herpetotropicos 1, 2931 .

Marmayou, J., Dubois, A., Ohler, A., Pasquet, E., Tillier, A., 2000. Phylogenetic relationships in the Ranidae (Amphibia, Anura): independent origin of direct development in the genera Philautus and Taylorana. C.R. Acad. Sci. Paris (Life Sci.) 323, 287-297.

van der Meijden, A., Vences, M., Meyer, A., 2004. Novel Phylogenetic relationships of the enigmatic brevicipitine and scaphiophrynine toads as revealed by sequences from the nuclear Rag-1 gene. Proc. R. Soc. B. 271 (Suppl. 2), S378-S381.

Minter, L.R., Burger, M., Harrison, J.A., Braack, H.H., Bishop, P.J., Kloepfer, D., 2004. Atlas and Red Data Book of the Frogs of South Africa, Lesotho and Swaziland. Smithsonian Institution, Washington.

Mittermeier, R.A., Myers, N., Thomsen, J.B., da Fonseca, G.A.B., Olivieri, S., 1998. Biodiversity hotspots and major tropical wilderness areas: approaches to setting conservation priorities. Conserv. Biol. $12,516-520$.

Murphy, W.J., Eizirik, E., O’Brien, S.J., Madsen, O., Scally, M., Douady, C.J., Teeling, E., Ryder, O.A., Stanhope, M.J., de Jong, W.W., Springer, M.S., 2001. Resolution of the early placental mammal radiation using Bayesian phylogenetics. Science 294, 2348-2351.

Myers, N., Mittermeier, R.A., Mittermeier, C.G., da Fonseca, G.A.B., Kent, J., 2000. Biodiversity hotspots for conservation priorities. Nature 403, 853-858.

Nylander, J.A.A., 2002. MrModeltest v1.0b. Program distributed by the author. Department of Systematic Zoology, Uppsala University.

Palumbi, S., Martin, A., Romano, S., McMillan, W.O., Stice, L., Grabowski, G., 1991. The Simple Fool's Guide to PCR. Version 2. Privately published document compiled by S. Palumbi, Department of Zoology, University Hawaii, Honolulu

Posada, D., Crandall, K.A., 1998. Modeltest: testing the model of DNA substitution. Bioinformatics 14, 817-818.

Purvis, A., Agapow, P.-M., Gitlleman, J.L., Mace, G.M., 2000. Nonrandom extinction and the loss of evolutionary history. Science 288 , $328-330$

Roelants, K., Jiang, J., Bossuyt, F., 2004. Endemic ranid (Amphibia: Anura) genera in southern mountain ranges of the Indian subcontinent represent ancient frog lineages: evidence from molecular data. Mol. Phylogenet. Evol. 31, 730-740.

Sanchiz, B., 1998. Encyclopedia of Palaeoherpetology, Part 4. Salientia. Pfeil, München

Savage, J.M., 1973. In: Vial, J.L. (Ed.), Evolutionary Biology of the Amphibians: Contemporary Research on Major Problems. University of Missouri Press, Columbia, pp. 351-445.

Seddon, J.M., Baverstock, P.R., Georges, A., 1998. The rate of mitochondrial12S rRNA gene evolution is similar in freshwater turtles and marsupials. J. Mol. Evol . 46, 460-464.

Sokol, O.M., 1977. A subordinal classification of frogs (Amphibia: Anura). J. Zool. Lond. 182, 505-508. 
Springer, M.S., Cleven, G.C., Madsen, O., De Jong, W.W., Waddell, V.G., Amrine, H.M., Stanhope, M.J., 1997. Endemic African mammals shake the phylogenetic tree. Nature 388, 61-64.

Springer, M.S., Debry, R.W., Douady, C., Amrine, H.M., Madsen, O., De Jong, W.W., Stanhope, M.J., 2001. Mitochondrial versus nuclear gene sequences in deep-level mammalian phylogeny reconstruction. Mol. Biol. Evol. 18, 132-143.

Springer, M.S., Murphy, W.J., Eizirik, E., O’Brien, S.J., 2003. Placental mammal diversification and the Cretaceous-Tertiary boundary. Proc. Natl. Acad. Sci. USA 100, 1056-1061.

Stuart, S.N., Chanson, J.S., Cox, N.A., Young, B.E., Rodrigues, A.S.L., Fischman, D.L., Waller, R.W., 2004. Status and trends of amphibian declines and extinctions worldwide. Science 306, 17831786.

Swofford, D.L., 2002. PAUP*. Phylogenetic analysis using parsimony (* and other methods), v. 4beta10. Sinauer Associates, Sunderland, Massachusets

Thompson, J.D., Higgins, D.G., Gibson, T.J., 1994. CLUSTAL W: improving the sensitivity of progressive multiple sequence alignments through sequence weighting, position specific gap penalties and weight matrix choice. Nucl. Acids Res. 22, 46734680.

Thorne, J.L., Kishino, H., 2002. Divergence time and evolutionary rate estimation with multilocus data. Syst. Biol. 51, 689-702.

Thorne, J.L., Kishino, H., Painter, I.S., 1998. Estimating the rate of evolution of the rate of molecular evolution. Mol. Biol. Evol. 15, 1647-1657.
Vences, M., Glaw, F., Kosuch, J., Das, I., Veith, M., 2000. Polyphyly of Tomopterna (Amphibia: Ranidae) based on sequences of the mitochondrial $16 \mathrm{~S}$ and 12S rRNA genes, and ecological biogeography of Malagasy relict amphibian groups. In: Lourenço, W.R., Goodman, S.M. (Eds.), "Diversité et Endémisme de Madagascar". Mémoires de la Société de Biogéographie, Paris, pp. 229-242

Vences, M., Glaw, F., 2001. When molecules claim for taxonomic changes: new proposals on the classification of Old World treefrogs (Amphibia, Anura, Ranoidea). Spixiana 24, 85-92.

Vences, M., Kosuch, J., Glaw, F., Böhme, W., Veith, M., 2003a. Molecular phylogeny of hyperoliid treefrogs: biogeographic origin of Malagasy and Seychellean taxa and re-analysis of familial paraphyly. J. Zool. Syst. Evol. Res. 41, 205-215.

Vences, M., Vieites, D., Glaw, F., Brinkmann, H., Kosuch, J., Veith, M., Meyer, A., 2003b. Multiple overseas dispersal in amphibians. Proc. R. Soc. Lond. B 270, 2435-2442.

Vences, M., Kosuch, J., Rödel, M.-O., Lötters, S., Channing, A., Glaw, F., Böhme, W., 2004. Phylogeography of Ptychadena mascareniensis suggests transoceanic dispersal in a widespread African-Malagasy frog lineage. J. Biogeogr. 31, 593-601.

Verheyen, E., Salzburger, W., Snocks, J., Meyer, A., 2003. The origin of the superflock of cichlid fishes from Lake Victoria, East Africa. Science 300, 325-329.

Wild, E.R., 1995. New genus and species of Amazonian microhylid frog with phylogenetic analysis of New World genera. Copeia 1995, 837-849. 